\title{
The Relation of Work Motivation, Work Discipline on Teacher Performance Through Teacher Professional Attitute
}

\author{
Anshari Shaleh *, Suhaimi, Ngadimun \\ Master Program of Education Management, Universitas Lambung Mangkurat, Banjarmasin 70123, \\ Indonesia
}

Article history:

Submission November 2019

Revised June 2020

Accepted June 2020

*Corresponding author:

E-mail: Anshari.hst@gmail.com

\begin{abstract}
Teacher performance is an activity in learning which is expected to be able to improve the quality and relevance of education. In the implementation of school, performance is influenced by many factors and interrelated for example work motivation, work discipline, and teacher professional attitude. This research aims to analyze the relationship between work motivation, teachers' professional attitude, discipline, and performance. Data were obtained from 173 elementary school teachers at the district of South Labuan Amas, through questionnaires and analyzed using the path analysis. The result of this research shows that there is a strong relationship between work motivation with teacher professional attitude, performance, and discipline. There is a strong relationship between work motivation with the teacher's performance, discipline, and professional attitude. Furthermore, there is a weak relation between work discipline and the teacher's professional attitude, discipline, and attitude. Advice this research to increase the factors that affect the teacher performance, the school should reward teachers for performance.
\end{abstract}

Keywords: Work motivation, work discipline, teacher professional attitude, teacher performance

\section{Introduction}

The teacher plays an important and strategic role in educational activities within or outside the school environment. This means that the effort to (Siska, 2017) increase education quality is dependent on the teacher, and they need to be always motivated to increase their performance. According to professional teachers are teachers who prioritize education quality. Teacher services must fill the standardization community needs, nation, users, and sensitize learners' abilities based on the potential and skills possessed by each individual.

At the operational stage, they are also the determinant of educational success through their various performances at the institutional, instructional, and experimental levels. In line with, they also help to guide, teach, and carry out practicals with students. Teachers with the soul, spirit, and strong nationality value act as role models for creating a positive environment for students. Sardiman (2000) stated that in the educational process, the activities of "educating," "teaching," and "guiding" are inseparable. In this case, the teacher does not transfer knowledge and values while providing "guidance" to students in the learning process.

Juhdi stated that the role of a teacher in educational development includes: (a) instilling values, (b) building character, (c) central learning, (d) providing assistance and encouragement, (e) conducting supervision and coaching, 
(f) discipline children. This is related to teacher performance with the intended behavior, which is an activity in the learning process. According to the Republic of Indonesia Law No. 20 of 2003 concerning National Education System article 39 paragraphs (2), "Educators are professionals tasked with planning, implementing, assessing, and conducting research as well as community service, following the learning process for educators.

According to Rusyan et al. (2000), "One factor that influences teacher performance is motivation." Mangkunegara (2005) also stated that work motivation is a condition associated with efforts to arouse, direct, and maintain behavior related to the environment.

Motivation is a force that drives a person to work, and it is referred to as a morale booster in psychology (Anoraga, 2009) Teachers tend to possess high work motivation when their physical and mental needs are met, which enables them to function optimally (Yulinda, 2015).

Apart from work motivation, the discipline also needs to be considered in improving teacher performance. Rachman and Savitri (2009) defined discipline as an effort to control oneself and the mental attitude of individuals or communities in developing compliance and obedience to rules and regulations based on encouragement and awareness.

Apart from motivation and discipline, a teacher needs to possess a professional attitude by mastering the ins and outs of education. According to (Danim, 2010) teacher professional competence is a high ability and au- thority in carrying out their professions. Luthans (2008) stated that a professional attitude is a positive and pleasant emotional state of a person and an assessment of a job and work experience. Based on the description above, this article aims at determining the relationship between work motivation, discipline, teacher's professional attitude and performance, on elementary schools in the district of Labuan Amas Selatan, Hulu Sungai Tengah Regency.

\section{Material and Methods}

The populations of this research are all 305 teachers spread across 27 elementary schools located in South Labuan Amas District spread across 27 schools in the 2019/2020 school year.

The sample table developed by Krejcie and Morgan were used to obtain a total of 173 teachers from the sample of 305 . This type of research is a quantitative research using SPSS version 21. The proving Assumptions through testing the analysis requirements are the normality test, classical descriptive, and analysis describing data obtained from respondents regarding work motivation, work discipline, professional attitudes, and teacher performance. The analysis tool uses the path to determine the relationship between variables.

Furthermore, a questionnaire containing questions on work motivation, discipline, teacher professional attitudes, and performance were used to obtain data on the respondents' experiences. The results of the questionnaire were then analyzed using path analysis. Hence, the model of this path analysis is depicted in Figure 1 below.

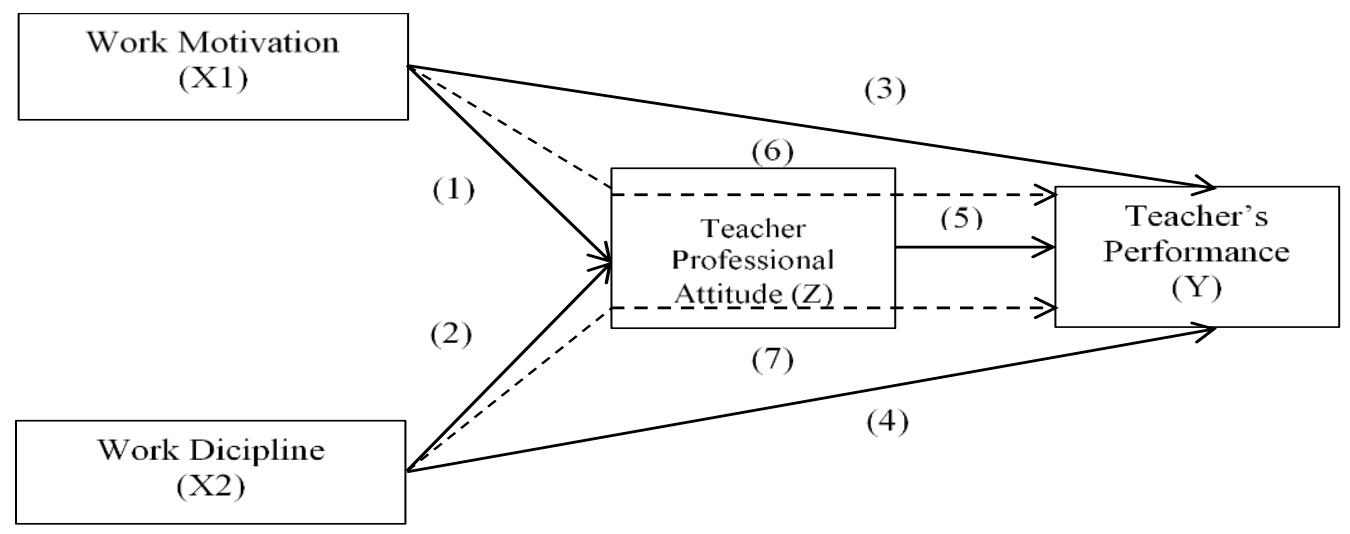

Figure1. Path model 


\section{Results and Discussion}

The direct relationship of work motivation with the teacher professional attitude

The result of path analysis between work motivations with the teacher professional attitude was 0.840 , which means that there is a strong relationship between both variables. The same result was also found by Nellitawati (2018) in research conducted at SMK in Padang City. The research found that teacher work motivation has a strong relationship with professionalism. Furthermore, research conducted by Panagiotopoulos et al. (2018) also showed that motivation contributed to satisfying the professional needs of employees in Egypt University.

Motivation is a force that drives a person to carry out work, and it is defined as a morale booster in psychology (Anoraga, 2007). According to Mangkunegara (2005), it is related to the efforts to generate, direct, and maintain behavior related to the work environment. With high motivation, teachers are encouraged to work responsibly (Yulinda, 2016). According to Veithzal, it comprises three sources, namely: (a) development possibility, (b) Type of work, (c) Feeling pride following the company where they work.

Work motivation is a force to move oneself to achieve set goals. A person's positive mental attitude towards work situations strengthens their motivation. Attitudes are basic variables that provide clues to changes in a person's behavior.

A teacher's profession, need to be based on attitudes and beliefs with a dedication to the nation, and humanity, in educating and developing a reliable generation. Therefore, when education is driven by motivation, the teacher tends to work optimally to achieve success. With a basis of love, the teacher ensures the best education is instilled in students.

\section{The direct relationship of work discipline with the teacher professional attitude}

The results of the path analysis between Work Discipline and Professional Attitudes of Teachers showed a value of 0.367 , which means that a weak relationship exists between both variables. Research conducted by Hasbullah and Moeins (2014) stated that there is a re- lationship between professionalism and discipline of teachers in Kerawang District. Furthermore, both variables have a significant influence on employee performance (Hafid \& Fajariani, 2019).

Discipline is a prerequisite for the formation of attitudes, behaviors, and living conditions, which enables the employee to carry out their tasks successfully. Its functions include managing a life together, building/training personality, coercion, and discipline.

Furthermore, its development is important because many of the benefits are for schools and teachers. With the discipline of teachers, school activities are carried out in an orderly and smooth manner, with learning properly implemented to achieve curriculum targets. Besides, student achievements are also optimally realized. Furthermore, there is a balance between work disciplines, with an increase in attitudes towards the teaching profession, which consists of experienced intellectual capacity, morals, faith, devotion, discipline, responsibility, broad educational insight, managerial ability, skills, and creativity. They also possess the ability to understand the potential, characteristics, and problems of student development, their study plans, and careers to research as well as develop an adequate curriculum (Suryosubroto, 2008).

\section{The direct relationship of between work mo- tivations with the performance}

The results of the path analysis between work motivation and teacher performance showed a value of 0.755 , which means that there is a strong relationship between both variables.

The results of this study are supported by the results of the research conducted by Mohamud et al. (2017) in several companies in Somalia, which showed that work motivation greatly affected the workers. In Indonesia, Andarwati (2018) conducted similar research at the Tax Office in Surakarta, which found that employee performance supported by labor, increased work. Nabi et al. (2017) also stated that the performance of employees at Karmasangsthan Bank Limited, Bangladesh, was significantly supported by their motivation. 
Several other studies also found related research results in the field of education. For instance, Afful-Broni (2012), in a study at the University of Mines and Technology in Ghana, found that the performance of lecturers in the field required motivation. IP and GO (2018), in research at a state tertiary institution in Nigeria, also found that employees and lecturers motivation of work needed for optimal functionality.

Shahzadi et al. (2014) examined 180 teachers to determine their work motivation and performance. This was also in line with the research conducted by Bangun (2012) that also found that the higher the work motivation of a teacher, the better would be on the teacher's performance.

Motivation is internal and external encouragement. A teacher involved in psychological aspects, needs, motivates and directs activities to produce decisions that are directed to the goals that have been provided following their tasks.

Similarly, those that are self-motivated tend to use their abilities, expertise, skills, and time to provide a solution when needed. A person's motivation starts with the needs, desires, and encouragement to achieve set goals. This indicates strong support, effort, intensity, and willingness to sacrifice for the sake of achieving goals. Therefore, the stronger the drive or motivation and enthusiasm, the better the performance.

\section{The direct relationship of work discipline with teachers performance}

The path analysis result between work discipline and teacher performance showed a value of 0.898 , which means that there is a strong relationship between both variables.

The results of this study are supported by the research conducted by Elqadri et al. (2015), which stated that the discipline of workers in the Bangkalan Tona'an market affected their performance. Similar results were also found by Razak et al. (2018), in research conducted at PT. ABC Makasar showed that the discipline of employees in the company was influenced by their performance. The higher their discipline, the better their performance. This is also in line with the research conducted by Heriyanto et al. (2018) at the Ptarama Tax Office in North Malang, from which it is concluded that employee's work discipline in the tax office has a great influence on their performance. Similarly, the study conducted by Dapu (2015), found that the performance of workers at PT. Trakindo Manado is influenced by their level of discipline.

Hasibuan (2010) defined discipline as the awareness and willingness of a person to obey all applicable rules and social norms. Without good discipline, it is difficult for a person or organization to achieve its set goals. Work discipline is an inner feeling of happiness, sadness, or passion for conducting a job. It is one of the factors that affect the value of performance. Therefore there is an attachment between both variables which determines the success or failure of an organization. The teacher is one of the keys to achieving educational, therefore thy need to display self-discipline, which tends to affect their performance greatly.

The act as parents in school and are mandated to educate, train, guide, and direct the potential of students in realizing their dreams. Teachers need to be able to provide the best performance education to students for them to achieve success.

\section{The direct relationship between teacher pro- fessional attitude and performance}

The path analysis results between the teacher professional attitudes with the performance showed a value of 0.751 , which means that there is a strong relationship between both variables. The results of this study are supported by the research conducted by Waterkamp et al. (2017), which found that professionalism has a very significant influence on employee performance in banks. Similarly, Permanasari et al. (2014) found that professionalism had a positive effect on the performance of lecturers at the Faculty of Economics, UPN Veteran, East Java. Besides, research conducted by Iswanto (2017) also showed that professionalism greatly affected the performance of workers in the BPJS office in Pekanbaru. The teacher's professional attitude towards legislation contributes to their work quality and accuracy. 
In this case, the planning and implementation of teacher programs are guided by provisions set by the government. However, this does not yet reflect their potential as educators. According to PP No. 74 of 2008 articles 1.1 and Law no. 14 of 2005, concerning teachers and lecturers, they are tasked with educating, teaching, guiding, directing, training, and evaluating students through formal, basic, and secondary education. The teachers need to instill performance to improve their achievement. An increase in their tendency to respond to stimuli improves their performance. The teachers need to like their profession in terms of economics, social status, and achievements for excellent performance.

The act of teaching is a profession therefore; teachers need to improve their work quality in the organization where they find themselves. Besides, they can improve work accuracy while socializing properly with colleagues. The Indonesian Teacher professional organization (PGRI) is aimed at strengthening and developing the teaching profession, through adequate communication on new attributes.

Teachers with a positive attitude towards work, tend to display perceptions and satisfaction of results for performance, which in turn reflects on them professionally. In carrying out the task, the teacher is faced with formal and informal situations. Formally the teacher carries out the task with the rules set by the government and informally by being a role model through improving the quality, initiative, ability, and communication.

The direct relationship between work motivation and performance through teacher professional attitude

The results of the path analysis between work motivation with performance through professional attitudes showed a value of 0.631 , which means that there is a strong relationship between both variables. Hanaysha and Majid (2018) stated that motivation plays an important role in increasing company productivity and organizational commitment. Besides, research conducted by Chaudhary and Sharma (2012) also found that motivation influences the performance and productivity of workers in private companies. Similarly, Omollo (2015) researched the effect of motivation on employee performance at commercial banks in Kenya with the same results. Ali et al. (2016) stated that motivation plays an important influence on the performance and job satisfaction of employees using a software company located in Pakistan. Furthermore, these results are also supported by research conducted by Dobre (2013), which stated that workers' motivation affects organizational performance.

Independent motivators possess the abilities, expertise, skills, energy, and time to carry out their obligations for an organization to achieve its goals.

Employees work professionally due to high motivation, which enables them to carry out their duties with enthusiasm and energy. It also makes them work professionally to achieve maximum goals and performance. This is similar to the research conducted by Öberg and Bringselius (2015), which stated that professionalism plays an important role in organizational performance. The results of the study are also supported by the results conducted by Mrope (2017), which found a positive impact on workers' performance. The more professional the workers, the better their performance.

\section{The indirect relationship between work dis- cipline with performance through teacher professional attitude}

The path analysis between work discipline and performance through teachers' professional attitudes showed a value of 0.276 , which means that there is a weak relationship between both variables. However, discipline remains an important factor in an organization. This is similar to the research conducted by Sarwani (2016), which stated that discipline plays an important role in workers' performance. Similar results were also found by Priyono et al. (2016), which stated that discipline and motivation affect workers' performance. Similarly, the research conducted by Simatupang and Putu. (2018) stated that discipline, motivation, and commitment affect employee performance, which is in line with the research conducted by Kuncorowati and Rokhmawati (2018). In all aspects of life, rules, and regula- 
tions are utilized to limit the attitude, movement, and behavior of workers. These regulations are meaningless when there is no commitment and sanctions for violators. Discipline in the work environment is needed because it encourages the achievement of organizational goals. Therefore, a person with a good work discipline tends to acquire useful advantages for relevant institutions, which indirectly raises feelings or attitudes towards the profession. Work discipline influences the productivity of a company (Nwinyokpugi, 2015). It also influences organizational commitment, as reported in the research conducted by Mangkunegara and Octorend (2015) at PT. Indonesian Chest. Other research conducted by Anthony (2017) also shows that work discipline has a significant effect on employee performance. Besides, the research conducted by Itang (2015) found that worker discipline affected the quality of service.

Furthermore, when properly carried out, it delivers an educator with the good performance following organizational goals. Due to high teachers' discipline, they are expected to work hard in carrying out their duties with optimal ability used to instill knowledge to students with innovation to ensure more lessons are properly delivered.

Teachers with high professional attitudes are expected to possess a high level of self-confidence and enthusiasm in implementing and improving their professional competencies. A research conducted by Rulandari (2017) showed that professionalism has a significant influence on workers' performance.

\section{Conclusion and Recommendation}

The elementary school teachers in the South Labuan Amas District, Hulu Sungai Tengah Regency has a strong relationship between work motivation with teachers' professional attitudes, performance, and discipline. However, there is a weak relationship between the work discipline with teachers' professional attitudes and performance.

We suggest to schools that they need to improve teachers motivation through rewards as this helps to motivate them to work harder; more effective learning activities need to be created to adjust the characteristic of each student; effort needs to be made to increase the feeling between teachers through formal or informal meeting; the teachers need to be fair to all the students by paying attention to their characteristics and development; and subsequent researchers need to determine the factors with the ability to influence teacher performance asides to work motivations, discipline, and professional attitude.

\section{Acknowledgment}

The authors are grateful to all teachers in the South Labuan Amas District, Hulu Sungai Tengah Regency, and Education Management Master Program, Universitas Lambung Mangkurat for their support and assistance in carrying out this research.

\section{References}

Afful-Broni, A. (2012). Relationship between Motivation and Job Performance at the University of Mines and Technology, Tarkwa, Ghana: Leadership Lessons. Creative Education, 3(3), 309-314. doi:10.4236/ce.2012.33049

Ali, A., Bin, L. Z., Piang, H. J., \& Ali, Z. (2016). The Impact of Motivation on the Employee Performance and Job Satisfaction in IT Park (Software House) Sector of Peshawar, Pakistan. International Journal of Academic Research in Business and Social Sciences, 6(9), 297-310. doi:10.6007/IJARBSS/v6-i9/2311

Andarwati, M. (2018). The Effect of Motivation on Employee Performance Through Employee Satisfaction of The Tax Office in Surakarta. International Journal of Economics, Business and Accounting Research, 2(1), 34-38. doi:10.29040/ijebar.v2i01.230

Anoraga, P. (2009). Manajemen Bisnis. Semarang: PT. Rineka Cipta.

Anthony, A. E. (2017). Effects of Discipline Management on Employee Performance in an Organization: The Case of County Education Office Human Resource Department,Turkana County. International Academic Journal of Human Resource and Business Administration, 2(3), 1-18.

Bangun, W. (2012). Manajemen Sumber Daya Manusia. Jakarta: Erlangga.

Chaudhary, N., \& Sharma, B. (2012). Impact of Employee Motivation on Performance (Productivity) In Private Organization. International Journal of Business Trends and Technology, 2(4), 29-35. 
Danim, S. (2010). Profesionalisasi dan Etika Profesi Guru. Jakarta: Kencana Prenada Media Group.

Dapu, V. A. (2015). The Influence of Work DIscipline, Leadershio, and Motivation on Employee Performance at PT. Trakindo Utama Manado. Jurnal Riset Ekonomi, Manajemen, Bisnis, dan Akuntansi, 3(3), 352-361.

Dobre, O.-I. (2013). Employee motivation and organizational performance. Review of Applied Socio- Economic Research, 5(1), 53-60. Retrieved from http://www.reaser.eu

Elqadri, Z. M., Wardoyo, D. T., \& Priyono. (2015). The Influence of Motivation and Discipline Work against Employee Work Productivity Tona'an Markets. Review of European Studies, 7(12), 59-66. doi:10.5539/res.v7n12p59

Hafid, H., \& Fajariani, N. (2019). Hubungan Profesionalisme, Komitmen Organisasi dan Kinerja Dosen pada STIE Muhammadiyah Mamuju. Kinerja, 16(1), 58-68. doi:10.29264/jkin.v16i1.5189

Hanaysha, J. R., \& Majid, M. (2018). Employee Motivation and its Role in Improving the Productivity and Organizational Commitment at Higher Education Institutions. Journal of Entrepreneurship and Business, 6(1), 17-28. doi:10.17687/JEB.0601.0

Hasbullah, R., \& Moeins, A. (2014). The Influence of Professionalism, Achievement Motivation and Empowerment Against the Work Discipline and Its Implication on Teacher Performance: Empirical Study on High School teachers in Karawang Regency. International Journal of Business andCommerce, 5(6), 18-36.

Hasibuan, M. S. (2010). Manajemen Sumber Daya Manusia. Jakarta: PT Bumi Aksara.

Heriyanto, T., Naser, J. A., \& Setia, K. A. (2018). The Effect of Competence and Discipline on Work Motivation and Impact on Employee Performnace of Pratama Tax Office in Malang Utara. Management and Economics Journal, 2(3). doi:http://dx.doi.org

Iswanto, J. (2017). Kompetensi, Profesionalisme Kerja, dan Kinerja Karyawan. Jurnal Ilmu Administrasi Negara, 14(2), 184-191.

Itang. (2015). Work Discipline and Work Competence with Quality of Service in the Office of Religious Affairs (KUA) District of Mount Kencana Lebak Regency of Banten. Journal of Management and Sustainability, 5(3). doi:10.5539/jms.v5n3p132

Kuncorowati, H., \& Rokhmawati, H. N. (2018). The Influence of Communication and Work Discipline on the Employee Performance. Journal of Arts, Science \& Commerce, 9(2), 613. doi:10.18843/rwjasc/v9i2/02

Luthans, F. (2008). Organizztional Behavior. New York: McGrawHill Companies, Inc.

Mangkunegara, A. A. (2005). Manajemen Sumber daya Manusia Perusahaan . Bandung: PT Remaja Rosdakarya.
Mangkunegara, A. P., \& Octorend, T. R. (2015). ffect of Work Discipline, Work Motivation and JobSatisfaction on Employee Organizational Commitment in the Company. Universal Journal of Management, 3(8), 318-328. doi:10.13189/ujm.2015.030803

Mohamud, S. A., Ibrahim, A. A., \& Hussein, J. M. (2017). The Effect of Motivation on Employee Performance: Case Study in Hormuud Company in Mogadishu Somalia. International Journal of Development Research, 7(11), 17009-17016.

Mrope, N. P. (2017). The Effect of Prefessionalism in Preformance of Procurement Function in the Public Sector: Eexperience from the Tanzanian Public Entities. International Journal of Business and Management Review, 5(6), 48-59.

Nabi, M. N., Islam, M. M., Dip, T. M., \& Hossain, M. A. (2017). Impact of Motivation on Employee Performances: A Case Study of Karmasangsthan Bank Limited, Bangladesh. Arabian Journal of Business and Management Review, 7(1), 1-8. doi:10.4172/2223-5833.1000293

Nellitawati, N. (2018). Motivation and innovation role of school's principal in improving teacher professionalism. The International Journal of Counseling and Education, 3(2), 4856. doi:10.23916/0020180313520

Nwinyokpugi, P. N. (2015). Workplace Discipline: A Catalyst For Organizational Productivity In Nigeria. International Journal of Innovative Research and Advanced Studies, 2(3), 1-5.

Öberg, S. A., \& Bringselius, L. (2015). Professionalism and Organizational Performance in the Wake of New Managerialism. European Political Science Review, 7(4), 499-523. doi:10.1017/S1755773914000307

Omollo, P. A. (2015). Effect of motivation on employee performance of commercial banks in Kenya:A casestudy of KenyaCommercial Bank in Migori County. International Journal of Human Resource Studies, 5(2), 87-103. doi:10.5296/ijhrs.v5i2.7504

Panagiotopoulos, G., Petta, E., \& Karanikola, Z. (2018). The Contribution of Motivation to Job Satisfaction: A Survey of Technological Educational Institute Employees of Western Greece. European Journal of Training and Development Studies, 5(3), 18-26.

Permanasari, R., Setyaningrum, R. M., \& Sundari, S. (2014). Relationship Model between Competence, Professionalism and Performance Teaching. Jurnal Bisnis, Manajemen \& Perbankan, 1(2), 157-174.

Priyono, Marzuki, \& Susatyo, Y. (2016). Pengaruh Disiplin dan Motivasi terhadap Kinerja Pegawai. Journal of Global Economics, Management and Business Research, 5(3), 212220. Retrieved from www.ikpress.org

Rachman, E., \& Savitri, S. (2009). Anda Bisa! Menciptakan Masa Depan: Anda Sutradaranya! Jakarta: PT. Gramedia Pustaka Utama. 
Razak, A., Sarpan, S., \& Ramlan, R. (2018). Effect of Leadership Style, Motivation and Work Discipline on Employee Performance in PT. ABC Makassar. International Review of Management and Marketing, 8(6), 67-71. doi:10.32479/irmm.7167

Rulandari, N. (2017). The Effect of Supervision and Professionalism on Staff Performance at the Office of Social Affairs in East Jakarta Administrative City. International Journal of Humanities and Social Science, 7(2), 184-192.

Rusyan, A. T., Kusdianar, A., \& Arifin, Z. (2000). Pendekatan dalam Proses Belajar Mengajar. Bandung: Remaja Karya.

Sardiman, A. M. (2000). Interaksi \& Motivasi Belajar Mengajar. Jakarta: Rajawali Press.

Sarwani. (2016). The effect of work discipline and work environment on the performance of the employee. SInergi, 6(2), 53-67.

Shahzadi, I., Javed, A., Pirzada, S. S., Nasreen, S., \& Khanam, F. (2014). Impact of Employee Motivation on Employee
Performance. European Journal of Business and Management, 6(23), 169-166.

Simatupang, A. C., \& P., P. S. (2018). The Effect of Discipline, Motivation and Commitment to Employee Performance. OSR Journal of Business and Management, 20(6), 31-37.

Siska, A. J. (2017). Pengaruh disiplin dan motivasi kerja terhadap kinerja guru pada SMAN 1 Canduang Kabupaten Agam. JUSIE Uurnal Sosial dan Ilmu Ekonomi), 1(2), 1-10. doi:10.36665/jusie.v1i02.139

Suryosubroto, B. (2008). Manajemen Pendidikan di Sekolah. Jakarta: Rineka Cipta.

Waterkamp, C. I., Tawas, H., \& Mintardjo, C. (2017). Effect of Professionalism, Organizational Commitment, and Work Satisfaction, to Employees Performance in PT. Bank Rakyat Indonesia (PERSERO) Tbk Manado Branch. Jurnal Riset Ekonomi, Manajemen, Bisnis, dan Akuntansi, 5(2), 28082818.

Yulinda. (2015). Motivasi belajar. Jakarta: Gramedia Pustaka Utama 